УДК: 330.341.1:001.9

DOI: 10.24144/2078 -1431.2020.1(24).150-161

Іванна Довба,

кандидат економічних наук, доцент кафедри бізнес-адміністрування, маркетингу та менеджменту

Олеся Дюгованець, кандидат економічних наук, доцент, завідувач кафедри бізнес-адміністрування, маркетингу та менеджменту ДВНЗ «Ужгородський національний університет»

\title{
СВІТОВИЙ ДОСВІД ІННОВАЦІЙНОГО РОЗВИТКУ В УМОВАХ ЕКОНОМІКИ ЗНАНЬ
}

У статті представлено результати аналізу світового досвіду інноваційного розвитку в провідних країнах світу з метою вивчення можливості його впровадження у процес функціонування національної системи в умовах економіки знань. Досліджено світовий досвід інноваційного розвитку, зроблено висновки про доциільність впровадження в Украӥні досвіду інноваційного розвитку економіки США, країн-иленів ЄС, СНД, Японії, Китаю, В'єтнаму та ін.

Окреслено теоретичні положення і розроблено рекомендації щодо формування $i$ забезпечення інноваційного розвитку країни. Визначено можливості застосування запропонованих підходів до забезпечення інноваційного розвитку країни в умовах економіки знань, що сприятиме підвищенню рівня їі інноваційності та формуванню національної економічної системи.

Ключові слова: інновації, інноваційний розвиток, інноваційна діяльність, фінансування НДДКР, інноваційний індекс, світовий досвід інноваційного розвитку.

The results of the peculiarities analysis of innovatively active countries`development worldwide by comparing their innovative development are presented in the article.

The rating of the most innovative countries of the world, which are at different levels of economic development, is formed. Overall, the Global Innovation Index rankings 126 countries. According to statistics, Ukraine has been actively improving its positions for the last few years in the rating and by today is ranked forty-third. The five countries that make the most use of innovation are Switzerland, the Netherlands, Sweden, the United Kingdom, and Singapore.

In the course of the research, the author examines and generalizes the world experience of innovative development in the leading countries of the world with the purpose of its possible introduction in the process of the national economy functioning in the conditions of the knowledge economy.

Innovative development assessment in foreign countries makes it possible to state that state support for innovative development of regions proves the actualization of 
innovative development of regions and cities stimulation. It can be reached through the new technologies' introduction, support of universities, companies, regional centers with rational use of available resources and opportunities.

The improvement directions of Ukrainian regional innovative development are formulated as a result of the foreign experience generalization. To formulate a coherent program, the existing foreign experience of innovative economic development and institutional support of this process should be used. In this context, the results of the study make it possible to conclude that it is advisable to: familiarize yourself with the peculiarities of the formation and development of institutional support for the innovative economy of the US, EU member states, CIS, Japan, China and others; use certain elements of the experience of other countries of the world; focus material and financial resources on the phased implementation of economic modernization programs (USA, EU Member States, CIS Member States, Japan, China and In this context, the study results make it possible to conclude that it is advisable to: familiarize yourself with the peculiarities of the institutional support formation and development for the innovative economy of the US, EU member states, CIS, Japan, China, and others; use certain experience elements of other countries of the world; focus material and financial resources on the phased implementation of economic modernization programs (USA, EU Member States, CIS Member States, Japan, China, and other countries); support small technology businesses (Central and Eastern European countries); implement interstate technological projects, state support and control over the activities of technoparks and technopolis (EU countries).other countries); support small technology businesses (Central and Eastern European countries); implement interstate technological projects, state support and control over the activities of technoparks and technopoles (EU countries).

Keywords: innovations, innovative development, innovative activity, RED financing, innovation index, world experience of innovative development.

Постановка проблеми. Інноваційний розвиток $є$ вагомою складовою забезпечення збалансованого соціально-економічного зростання економіки країни. Актуалізація зазначеного розвитку зумовлюеться сучасними потребами господарювання і необхідністю формування інноваційного середовища, впровадження інноваційних технологій у багатогранних сферах і видах економічної діяльності, передусім у межах територіальної економічної системи. Сфера інноваційного розвитку є системоутворюючим елементом, що безпосередньо впливає на розвиток території, економічної системи країни, сприяючи підвищенню рівня задоволення поточних і перспективних суспільних потреб мешканців з одночасним дотриманням інтересів як регіональної економічної системи, так і держави в цілому.

Сучасні тенденції розвитку зарубіжних країн-лідерів у сфері інновацій демонструють постійне зростання ролі окремих територій, міст і регіонів як дедалі активніших суб'єктів інноваційної діяльності та безпосередніх учасників програм регіонального і національного інноваційного розвитку. 3 іншого боку, чимало ініційованих та підтриманих останнім часом у зарубіжних країнах проєктів у частині державного забезпечення в суспільно-соціальній сфері мають інноваційний характер [1, с. 96]. 3 огляду на це, виникає необхідність дослідження проблемних питань забезпе- 
чення інноваційного розвитку, передусім на основі державної підтримки, а також оцінювання і порівняння інноваційного потенціалу України та зарубіжних країн.

Анадіз останніх досліджень та публікацій. Результати досліджень інноваційного розвитку зарубіжних країн загалом представлені у працях таких науковців, як Бойко А.Н., Водянка Л.Д., Власкин Г.А., Ленчук Е.Б., Лопатинський Ю.М., Михелашвілі Н.Р., Овчинников В.В., Петровський А.Б., Пронічкин С.В., Татаринов В. В., Татаринов В. С., Стернін М.Ю., Удальцова Н.А., Цукерман В.А., Шепельов Г. І. та ін., де висвітлено теоретичні основи інноваційного розвитку в умовах економіки знань. Проте низка питань вимагає додаткових досліджень.

Мета написання наукової роботи полягає в оцінці та узагальненні світового досвіду інноваційного розвитку в провідних країнах світу для можливості впровадження його у процес функціонування національної системив умовах економіки знань.

Результати дослідження. Низька інноваційна активність українських виробників і недостатній рівень конкурентоспроможності української продукції на зарубіжних ринках висувають як першорядне завдання кардинальну зміну ситуації в сфері інноваційної діяльності в Україні. Для цього доцільно перш за все вивчити досвід передових економік світу в частині організації та стимулювання учасників інноваційної діяльності.

Історія становлення інноваційних економік показує різні приклади тимчасових рамок, необхідних для запуску, прискорення і підтримки інноваційного розвитку. При цьому зустрічаються приклади як країн, які планомірно рухалися до інноваційного розвитку, так і країн, які вчинили інноваційний ривок під впдивом державної політики [2].

Основним чинником зростання територіальної економічної системи є впровадження науково-технічних, освітніх, інформаційних технологій для підвищення рівня конкурентоспроможності інноваційного розвитку країни в умовах економіки знань.

При цьому така конкурентоспроможність досягається в основному за рахунок максимального залучення у виробництво дешевих природних і трудових ресурсів і за рахунок скорочення витрат на виробництво стандартних товарів і послуг. Західні країни вже перейшли до освоєння і розгортання нової - глобальної мережевої моделі інноваційного процесу, яка має на увазі кооперацію країн у проведенні інноваційних процесів, а також розподіл всіх етапів інноваційного процесу по різних країнах на основі міжнародного поділу праці.

Сучасний етап світогосподарського розвитку характеризується прискореними темпами науково-технічного прогресу і зростаючою інтелектуалізацією основних факторів виробництва. Інтенсивне проведення досліджень та розробка на їх основі новітніх технологій, вихід 3 ними на світові ринки і розгортання міжнародної інтеграції в науково-виробничій сфері формуе глобальну економіку, яка фактично стала стратегічною моделлю економічного зростання для індустріально розвинених країн в умовах економіки знань. Причому інтелектуальні ресурси разом з новітніми технологіями не 
тільки визначають перспективи господарського зростання, але і служать показником рівня економічної незалежності і добробуту країни, іiі національного статусу. Їх наявність у системі глобальних економічних зв'язків перетворюється на один з найважливіших факторів, що визначають конкурентоспроможність націонадьних економік, сенсом взаємодії яких дедаді виразніше стає орієнтація на створення технологічних інновацій загальносвітового застосування, також мають перспективи міжнародні ринки збуту й інтегруючі інноваційні системи окремих країн і регіонів [3].

Рівень економічного розвитку держав характеризують за допомогою різного роду індикаторів, які охоплюють майже 150 країн світу, де виробляється понад 99 \% сукупного світового ВВП і проживає більше 90 \% населення Землі. Для оцінювання росту економіки використовують, наприклад, індекс економічної свободи (Index of Economic Freedom) американського дослідницького центру «Фонд спадщини» (The Heritage Foundation) і газети «Уоллстріт»(The Wall Street Journal), а для оцінки інноваційного розвитку, наприклад, фінансову інформацію Агентства Блумберг (Bloomberg LP) та інші.

Інноваційна модель розвитку потребує витрат на фінансування науки не менше 2 \% ВВП (в Україні цей показник становить 0,3%). Країни, які досягли високих темпів економічного зростання за рахунок інноваційного чинника, а це Японія, США, Німеччина, Франція, Великобританія, відповідають цій вимозі [4]. Відмічені вище країни за даними Глобального фінансування досліджень та розробок (Global Research and Development Funding) займають провідні позиції у рейтингу країн світу за фінансуванням НДДКР за період 2010-2019 рр. (табл.1).

Таблиияя 1

Витрати на НДДКР, млрд. дол. США*

\begin{tabular}{|l|c|c|c|c|c|c|c|c|c|c|}
\hline \multicolumn{1}{|c|}{ Країни \роки } & $\mathbf{2 0 1 0}$ & $\mathbf{2 0 1 1}$ & $\mathbf{2 0 1 2}$ & $\mathbf{2 0 1 3}$ & $\mathbf{2 0 1 4}$ & $\mathbf{2 0 1 5}$ & $\mathbf{2 0 1 6}$ & $\mathbf{2 0 1 7}$ & $\mathbf{2 0 1 8}$ & $\mathbf{2 0 1 9}$ \\
\hline США & 415 & 427 & 436 & 450 & 485 & 496 & 522 & 538 & 566 & 581 \\
\hline Китай & 149 & 175 & 199 & 258 & 344 & 373 & 425 & 445 & 485 & 519 \\
\hline Японія & 148 & 152 & 158 & 163 & 163 & 165 & 186 & 186 & 191 & 193 \\
\hline Німеччина & 83 & 88 & 91 & 92 & 103 & 107 & 115 & 115 & 121 & 123 \\
\hline Південна Корея & 49 & 53 & 56 & 61 & 64 & 75 & 82 & 77 & 86 & 94 \\
\hline Індія & 33 & 38 & 41 & 42 & 62 & 66 & 74 & 85 & 90 & 93 \\
\hline Франція & 47 & 49 & 51 & 52 & 58 & 59 & 61 & 62 & 65 & 66 \\
\hline Росія & 23 & 25 & 27 & 38 & 54 & 51 & 56 & 58 & 62 & 62 \\
\hline Велика Британія & 39 & 41 & 42 & 44 & 44 & 45 & 49 & 49 & 50 & 51 \\
\hline Бразилія & 24 & 28 & 30 & 31 & 37 & 37 & 38 & 37 & 38 & 39 \\
\hline Україна & 1,01 & 1,8 & 1,44 & 1,2 & 0,65 & 0,63 & 0,91 & 2,88 & 3,02 & 3,12 \\
\hline
\end{tabular}

*Сформовано та доповнено авторами на основі джерел [5, с.36; 6; 7.] 
Узагальнення інформаційних даних засвідчує, що в країнах, які мають високий рівень досліджуваного розвитку, вагому роль відіграє державне регулювання інноваційних процесів, яке здійснюється як прямими методами (державна підтримка та фінансування), так і непрямими (стимулювання, створення сприятдивих умов упровадження інновацій тощо) [5, с. 36].

Одним 3 популярних показників служить Глобальний індекс конкурентоспроможності (Global Competitiveness Index), який публікуеться в щорічних звітах Всесвітнього економічного форуму (World Economic Forum) і показує, як наявні у країні ресурси використовуються, щоб забезпечити високий рівень добробуту громадян (Global Competitiveness Report). Цей індекс відображає макро- і мікроекономічні аспекти ділової активності в країні і включає більш ніж 110 факторів, об'єднаних у дванадцять блоків. А саме: якість державних і приватних інститутів; інфраструктура; макроекономічна стабільність; здоров'я; початкова освіта, вища освіта та професійна підготовка; ефективність ринку товарів; ефективність ринку праці; рівень розвитку фінансового ринку; рівень розвитку технологій; обсяг внутрішнього і міжнародного ринків; випуск нових товарів із застосуванням складних виробничих процесів; інноваційний потенціал [9].

Індекс конкурентоспроможності розраховується як зважена сума значень факторів, де кожному з блоків присвоюють свою вагу, і залежить від стадії економічного розвитку країни і доходу на душу населення. Верхні місця в рейтингах за 2012-2018 рр. за Глобальним індексом конкурентоспроможності займають Швейцарія, Сінгапур, США, Німеччина, Нідерланди, Фіндяндія, Гонконг, Швеція, Японія, Великобританія (табл. 2).

Таблиця 2

\section{Рейтинг країн світу за індексом гдобадьної конкурентоспроможності [5, с. 33]}

\begin{tabular}{|c|c|c|c|c|c|c|c|c|c|c|c|}
\hline № & $\begin{array}{c}\text { 2012-2013 } \\
\text { (144 краї- } \\
\text { ни) }\end{array}$ & № & $\begin{array}{c}\text { 2013-2014 } \\
\text { (148 кра- } \\
\text { їн) }\end{array}$ & № & $\begin{array}{c}\text { 2014-2015 } \\
\text { (144 краї- } \\
\text { ни) }\end{array}$ & № & $\begin{array}{c}2015- \\
2016(140 \\
\text { країн) }\end{array}$ & № & $\begin{array}{c}2016- \\
2017 \text { (138 } \\
\text { країн) }\end{array}$ & № & $\begin{array}{c}\text { 2017-2018 } \\
\text { (137 кра- } \\
\text { їн) }\end{array}$ \\
\hline 1 & Швейцарія & 1 & $\begin{array}{l}\text { Швейца- } \\
\text { рія }\end{array}$ & 1 & ія & 1 & $\begin{array}{l}\text { Швейца- } \\
\text { рія }\end{array}$ & 1 & $\begin{array}{l}\text { Швейца- } \\
\text { рія }\end{array}$ & 1 & $\begin{array}{l}\text { Швейца- } \\
\text { рія }\end{array}$ \\
\hline 2 & & 2 & & 2 & & & Сінгапур & 2 & Сінгапур & 2 & \\
\hline 3 & & 3 & & 3 & & & & 3 & & 3 & \\
\hline 4 & Швеція & 4 & геччи- & 4 & $\begin{array}{l}\text { Нідерлан- } \\
\text { ди }\end{array}$ & 4 & & 4 & & 4 & $\begin{array}{l}\text { Нідерлан- } \\
\text { ди }\end{array}$ \\
\hline 5 & $\begin{array}{l}\text { Нідерлан- } \\
\text { ди }\end{array}$ & 5 & США & 5 & $\begin{array}{l}\text { Німеччи- } \\
\text { на } \\
\end{array}$ & 5 & \begin{tabular}{|l|} 
Нідер- \\
ланди \\
\end{tabular} & 5 & $\begin{array}{l}\text { Нiдер- } \\
\text { ланди }\end{array}$ & 5 & $\begin{array}{l}\text { Німеччи- } \\
\text { на }\end{array}$ \\
\hline 6 & Німеччина & 6 & Івеція & 6 & & 4 & & 6 & Японія & 6 & Гонконг \\
\hline 7 & США & 7 & Гонконг & 7 & & 7 & & 7 & & 7 & Швеція \\
\hline 8 & $\begin{array}{l}\text { Велика } \\
\text { Британія } \\
\end{array}$ & 8 & $\begin{array}{l}\text { Нідерлан- } \\
\text { ди }\end{array}$ & 8 & $\begin{array}{l}\text { Велика } \\
\text { Британія } \\
\end{array}$ & 8 & $\begin{array}{l}\text { Фінлян- } \\
\text { дія } \\
\end{array}$ & 8 & $\begin{array}{l}\text { Фінлян- } \\
\text { дія }\end{array}$ & 8 & $\begin{array}{l}\text { Велика } \\
\text { Британія }\end{array}$ \\
\hline 9 & & 9 & & 9 & & 8 & & 9 & & 9 & Японія \\
\hline 10 & Японія & 10 & $\begin{array}{l}\text { Велика } \\
\text { Британія }\end{array}$ & 10 & Фінляндія & 10 & $\begin{array}{l}\text { Велика } \\
\text { Британія }\end{array}$ & 10 & $\begin{array}{l}\text { Велика } \\
\text { Британія }\end{array}$ & 10 & Фінляндія \\
\hline 11 & Україна & 84 & Україна & 76 & Україна & 79 & Україна & 85 & Україна & 81 & Україна \\
\hline
\end{tabular}


3 метою порівняння та оцінювання інноваційного розвитку краӥн широко використовується Глобальний інноваційний індекс (Global Innovation Index), який щорічно визначають провідна французька бізнес-школа Европейський інститут управління бізнесом (L'Institut Européend' Administration des Affaires - INSEAD), Корнелльський університет США i Всесвітня організація інтелектуальної власності (World Intellectual Property Organization) [9].

Рівень розвитку інновацій оцінюеться за майже 80 різними показниками, згрупованими в дві категорії: вхідні та вихідні. Вхідні показники відображають наявні ресурси і умови для проведення інновацій, які включають політичну, нормативну сфери, ділове середовище; людський капітал - освіту, дослідження та розробки; загальну інфраструктуру, інформаційно-комунікаційні технології, екологічну стійкість; кредити, інвестиції, торгівлю, конкуренцію, розвиток внутрішнього ринку; інноваційні зв'язки, творчих працівників, абсорбцію знань. Вихідні показники характеризують практичні досягнення при реалізації інновацій, які включають розвиток технологій створення, впливу і поширення знань; результати творчої діяльності у формі нематеріальних активів, творчих товарів, послуг, онлайн-творчості.

Починаючи з 2007 року, Всесвітня організація інтелектуальної власності щороку складає і публікуе Глобальний індекс інновацій (ГІІ). Він є міжнародним рейтингом, в межах якого їі експерти намагаються оцінити те, як різні країни світу розвивають інноваційні галузі економіки і намагаються втілити їх в життя.

При його складанні оцінюеться не тільки наукова, але і політична та економічна складові успіху, в тому числі якість інноваційного законодавства, відсутність перешкод для ведення бізнесу, рівень корупції та інші фактори, які не мають безпосереднього відношення до науки і технологій [10].

Інноваційний індекс розраховується як середньозважена сума оцінок за двома групами показників і показуе співвідношення витрат і ефективності зусиль 3 розвитку інновацій в країні. Верхні місця в рейтингах за 2013-2018 роки за Глобальним інноваційним індексом займають Швейцарія, Швеція, Великобританія, США, Нідерланди, Фіндяндія, Сінгапур, Данія, Ірландія, Люксембург, Гонконг, Німеччина, Південна Корея[8].

У новій версії щорічного рейтингу найбільш інноваційних країн світу Global Innovation Index Україна станом на 2018 рік піднялася на сім позицій - 3 50-го на 43-є місце [11]. Загалом у рейтингу Global Innovation Index представлено 126 країн. За даними статистики, останні кілька років Україна активно поліпшуе власні позиції. У 2017 році країна займала 50-ту сходинку рейтингу, у 2016-ому - 56-ту, а в 2015 році - 64-ту. Отже, за три останні роки Україні вдалося піднятися більш ніж на 20 позицій. П'ятірка країн, які найбільш ефективно використовують інновації: Швейцарія (лідер рейтингу восьмий рік поспіль), Нідерланди, Швеція, Великобританія, Сінгапур. На 6-му місці - Сполучені Штати Америки. У топ-десятку увійшли також Фінляндія, Данія, Німеччина та Ірландія. Китай 
знаходиться на 17-му місці, вперше увійшовши в топ-20.Росія опинилася на 46-му місці, опустившись на одну позицію за останній рік. Сусідні 3 Україною країни зайняли такі позиції: Польща - 39-ту, Молдова - 48-му, Білорусь - 86-ту [11].

У процесі дослідження інноваційного розвитку зарубіжних країн фахівці Всесвітньої організації інтелектуальної власності визнали Швейцарію світовим лідером в інноваційному розвитку та впровадженні нововведень у повсякденне життя, а Китай став єдиною країною «другого світу», що потрапив у двадцятку нового рейтингу. За даними Міжнародної організації інтелектуальної власності (WIPO), з усіх поданих у світі заявок на патенти, зареєстрованих у 2017 році у Китаї, Швейцарії належить 42,8 \%, США - 19,4%, Японії і Південній Кореї - по 10,2%, Европі - 5,1%, весь інший світ займає 15,8 \%.

Зазначений показник засвідчує, що глобальний інтелект перетікає із США (колишнього дідера в цій сфері) в Китай. Причому тенденція інноваційного зсуву в бік Китаю та Азії простежується давно, вже років десять-п'ятнадцять, і до того ж $з$ прискоренням: тільки за 2017 рік ми спостерігаємо зростання частки китайських заявок на патенти на 4,8 \%

Однак, як зазначено у доповіді «Европейське інноваційне табло 2017», Україна відстає за всіма показниками, окрім показників охоплення вищою освітою. Відносно сильні сторони інноваційної системи України - дюдські ресурси, інвестиції компаній та вплив зайнятості. Слабкі сторони - зв' язки та підприємництво, привабливість дослідницьких систем, інноватори. Так, аналіз даних підтвердив, що значення показника для України у 2016 році становило 28,9 \%, що свідчить про падіння на 4,2 \% порівняно 32010 роком. Таким чином, Україна належить до групи країн «повільні інноватори». За даними доповіді за 2017 рік, помітними відмінностями України є зниження ВВП на душу населення, нижчий і негативний темп приросту ВВП, нижчий і негативний темп приросту населення і менша його щільність. Серед показників з позитивною динамікою можна виділити кількість промислових зразків, обсяги експорту знаннєвомістких послуг та зростання кількості міжнародних спільних публікацій [14, 15].За рівнем інноваційної активності країни Европи за даними European Innovation Scoreboard діляться на 4 групи (табл. 3).

Таблиияя 3

Групи країн Європи за рівнем інноваційної активності за 2017 р.*

\begin{tabular}{|l|l|}
\hline \multicolumn{1}{|c|}{$\begin{array}{c}\text { Група } \\
\text { ефективності }\end{array}$} & \multicolumn{1}{c|}{ Країни } \\
\hline $\begin{array}{l}\text { Група 1. Лідери } \\
\text { інновацій }\end{array}$ & $\begin{array}{l}\text { Швейцарія }(169,4), \text { Швеція }(149,0), \text { Данія }(140,1), \text { Фіндяндія }(136,1), \\
\text { Нідерланди }(135,9), \text { Великобританія }(128,5), \text { Люксембург }(128,1), \\
\text { Німеччина }(126,5), \text { Бельгія }(124,4), \text { Ірландія }(122,7) .\end{array}$ \\
\hline $\begin{array}{l}\text { Група 2. Сильні } \\
\text { інноватори }\end{array}$ & $\begin{array}{l}\text { Австрія }(121,3), \text { Ісландія }(120,8), \text { Норвегія }(119,7), \text { Франція }(115,5), \\
\text { Ізраїль }(113,4), \text { Словенія }(97,6) .\end{array}$ \\
\hline
\end{tabular}




\begin{tabular}{|l|l|}
\hline $\begin{array}{l}\text { Група 3. Помірні } \\
\text { інноватори }\end{array}$ & $\begin{array}{l}\text { Чехія (87,1), Португалія }(85,2), \text { Мальта (84,5), Іспанія (83,9), Ес- } \\
\text { тонія }(83,2), \text { Кіпр }(81,0), \text { Італія (77,9), Литва (75,3), Сербія (70,3), } \\
\text { Уорщина (69,6), Греція }(68,8), \text { Словаччина (67,8), Туреччина } \\
(60,1), \text { Латвія }(59,8), \text { Польща }(56,7), \text { Хорватія }(54,2) .\end{array}$ \\
\hline $\begin{array}{l}\text { Група 4. Повіль- } \\
\text { ні інноватори }\end{array}$ & Болгарія $(48,0)$, Македонія $(47,9)$, Румунія $(32,9)$, Україна $(29,4)$. \\
\hline
\end{tabular}

*Сформовано за джерелом: [12]

Група країн із середнім і низьким рівнем доходу демонструє несподівано високі для свого рівня розвитку показники в області інноваційної діяльності в економіці знань. У 2018 році в групу «динамічних новаторів» увійшло 20 країн, тобто на три країни більше, ніж в 2017-ому. Шість 3 них, включаючи Кенію, Руанду і Південну Африку, розташовані в регіоні Африки на південь від Сахари, а ще п'ять - у Східній Европі.

Аналіз європейських країн свідчить про те, що одинадцять 320 перших місць в списку лідерів інноваційного розвитку займають європейські країни, включаючи першу трійку: Швейцарія (1 місце), Нідерланди (2) і Швеція (3) (табл.4).

Таблиця 4

Регіональні лідери в області інновацій

\begin{tabular}{|c|c|c|}
\hline Рейтинг & Країна & $\begin{array}{c}\text { Місце в глобадьному } \\
\text { рейтингу 2018 p. }\end{array}$ \\
\hline Північна Америка \\
\hline 1 & Сполучені Штати Америки & 6 \\
\hline 2 & Канада & 18 \\
\hline Північна Африка і Західна Азія \\
\hline 1 & Ізраїль & 11 \\
\hline 2 & Кіпр & 29 \\
\hline 3 & Об'єднані Арабські Емірати & 38 \\
\hline Південно-Східна Азія, Східна Азія і Океанія \\
\hline 1 & Сінгапур & 5 \\
\hline 2 & Республіка Корея & 12 \\
\hline 3 & Японія & 13 \\
\hline Свропа & Швейцарія \\
\hline 1 & Нідерланди & 2 \\
\hline 2 & Швеція & 3 \\
\hline 3 &
\end{tabular}

${ }^{*}$ Сформовано авторами 
Швейцарія утримує перше місце в рейтингу ГІІ восьмий рік поспіль. Вона лідируе за різними патентними та іншими показниками у сфері інтелектуальної власності займає другий рядок у списку за індексом виробництва високотехнологічної продукції. Вона також належить до групи світових лідерів за обсягом витрат на НДДКР і якістю місцевих ВНЗ.

Нідерланди займають друге місце в загальносвітовому рейтингу інноваційної діяльності. Країна має сильний взаємопов' язаний приватний сектор, який відмінно взаємодіє з університетами. Інтернаціоналізація цього сектора здійснюеться за рахунок експорту продукції на умовах ліцензій інтелектуальної власності.

Швеція займає третю сходинку в глобальному рейтингу. Країна знаходиться на першому місці за кількістю патентних заявок, поданих відповідною країною походження за процедурою Договору про

патентну кооперацію Всесвітньої організації інтелектуальної власності. Вона стимулюе ефективність онлайн-творчості [13].

Якщо проаналізувати Північну Америку, то у першій двадцятці рейтингу Глобального індексу інновацій2018 року представлені дві північноамериканські країни.

США посідають шосте місце в 2018 році, опустившись на дві позиції порівняно з 2017 роком; це частково пов' язано зі змінами моделей. В абсолютному вираженні США залишаються лідером за обсягом інноваційних витрат і результатів інноваційної діяльності, включаючи інвестиції в НДДКР, і займають друге після Китаю місце за кількістю дослідників, патентів і науково-технічних публікацій. Третій рік поспіль США випереджають Сполучене Кородівство за показником якості університетів: найвищі результати у Массачусетського технологічного інституту (MIT), Стенфордського і Гарвардського університетів.

Канада займає вісімнадцяте місце в загальному заліку: її сильні сторони - простота організації нового бізнесу і операції з венчурним капіталом.

Цього року всі країни і території Південно-Східної та Східної Азї, а також Океанії виявидися в першій сотні рейтингу ГІІ. Найкращі результати в цьому регіоні показали Сінгапур (5), Республіка Корея (12) і Японія (13).

Сінгапур посідає перше місце за ефективністю державного управдіння, якістю нормативно-правової бази та рівнем відтоку прямих іноземних інвестицій. Крім того, він дідируе за індексом політичної стабільності і безпеки, ринкової капіталізації, притоку прямих іноземних інвестицій, обсягом виробництва високотехнологічної продукції і чистого експорту високотехнологічних товарів.

Японія знаходиться на першому місці за рядом показників: обсягом валових внутрішніх витрат на НДДКР, що фінансуються приватним сектором, чисельністю сімейств патентів-аналогів, заявки на які подані в два або більше відомства, і надходженням від використання інтелектуальної власності.

Республіка Корея займає верхні рядки рейтингу за обсягом патентних заявок, поданих відповідною країною походження, і різними показниками, що дає кількісну оцінку зусиль в області НДАКР (обсяг валових 
внутрішніх витрат на НДДКР, НДДКР, що фінансуються і ведуться приватним сектором, а також чисельність науково дослідних кадрів на підприємствах). Країна також займає перше місце за обсягом промислових зразків, що реєструються тією чи іншою країною походження, і чистого експорту високотехнологічних товарів. Крім того, Корея знаходиться на восьмій сходинці рейтингу за новим показником створених мобільних додатків.

Аналіз регіону Північної Африки та Західної Азї демонструє, що шостий рік поспіль Ізраїль (11) і Кіпр (29) є лідерами в цьому регіоні. Третє місце належить Об'єднаним Арабським Еміратам.

Ізраїль утримуе провідні позиції за кількістю науково-дослідних кадрів, обсягом витрат на НДДКР, операціями з венчурним капіталом, обсягом НДДКР , що фінансуються приватним сектором, чисельністю науково-дослідних кадрів на підприємствах, експортом інформаційно-комунікаційних послуг.

Кіпр демонструє високі результати за рівнем доступу до кредитування, поширення знань та онлайн-творчості. Інші сильні сторони цієї країни: приплив і відтік прямих іноземних інвестицій, імпорт і експорт інформаційно-технологічних послуг. Кіпр також є світовим дідером за кількістю створених мобільних додатків.

Об'єднані Арабські Емірати мають високі показники за кількістю нових вищих навчальних закладів, рівнем розвитку кластерів, обсягом НДДКР, що фінансуються приватним сектором, чисельністю науково-дослідних кадрів, так само як за рівнем освіти, розвитку загальної інфраструктури та зв'язків в інноваційному ланцюгу.

Висновки і перспективи подадыших досдіджень. Завдання переходу до інноваційного розвитку економіки передбачає розроблення відповідної концепції і програми її реалізації. Для формування цілісної програми слід використовувати вже існуючий зарубіжний досвід інноваційного розвитку економіки та інституційного забезпечення цього процесу. У цьому контексті результати проведеного дослідження дозводяють ознайомитись $з$ особливостями формування і розвитку інституційного забезпечення інноваційної економіки багатьох країн світу та зробити висновки про доцільність:

- зосередження наявних незначних ресурсів на ключових напрямах модернізації економіки за прикладом Японії та країн Південно-Східної Азії з перших кроків селекційного господарського розвитку;

- застосування окремих елементів досвіду інших країн світу, до прикладу Китаю, щодо створення точкових територіальних центрів високотехнологічного розвитку;

- зосередження матеріальних і фінансових ресурсів на поетапному вивченні програм модернізації економіки США, країн-членів ЕС, країн-членів СНД, Японії, Китаю та ін.;

- здійснення підтримки малого технологічного бізнесу 3 досвіду країн Центрально-Східної Европи; реалізації міждержавних техноло- 
гічних проєктів з обов'язковою державною підтримкою і контролем за діяльністю технопарків і технополісів з досвіду країн $\mathrm{CC}$;

- урахування проблемних питань щодо впровадження інновацій за допомогою системи іноземного інвестування, що в подадьшому може призвести до істотного перерозподілу власності між національними і зарубіжними суб'єктами господарювання на користь останніх. Такий досвід уже накопичено в країнах Східної Европи, зокрема в Угорщині та Чехії.

Подальше дослідження може бути продовжено в контексті адаптації світових досягнень інноваційного розвитку та інституційного забезпечення інноваційної діяльності у сфері економіки знань.

\section{СПИСОК ВИКОРИСТАНИХ ДЖЕРЕ}

1. Газуда А. М., Довба I. В. Державне забезпечення інноваційного розвитку регіону: досвід зарубіжних країн// Науковий вісник Ужгородського націонадьного університету. Серія: Міжнародні економічні відносини та світове господарство.2018. №20 (1). С. 96-99.

2. Татаринов В. В., Татаринов В. С. Опыт развития и финансирования инноваций за рубежом и реади украинского рынка инноваций // Академічний огляд. 2013. № 2 (39). C. 162-169.

3. Опыт инновационного сотрудничества стран ЕС и СНГ .URL: http://iee.org.ua/ files/alushta/31-boyko-opyt_innov_sotrudn.pdf

4. Наукова та інноваційна діяльність (1990-2016). Джерела фінансування інноваційної діяльності. URL: http:// www.ukrstat.gov.ua/.

5. Лопатинський Ю. М., Водянка $А$. Д. Державне регулювання інноваційної діяльності: зарубіжний досвід// Інфраструктура ринку. 2018. № 16. URL: http://www. market-infr.od.ua/journals/2018/16_2018_ukr/7.pdf.

6. Global r\&d funding forecast // R\&D Magazine. URL: https://digital.rdmag.com/ researchanddevelopment/2018_global_r_d_funding_forecast?pg=1\#pg1

7. Global r\&d funding forecast // R\&D Magazine. URL: https://digital.rdmag.com/ researchanddevelopment/2019_global_r_d_funding_forecast?pg=1\#pg1

8. Національна інноваційна система США: характеристики, особливості, шляхи розвитку.URL: ttps://cyberleninka.ru/article/n/natsionalnaya-innovatsionnayasistema-ssha-harakteristiki-osobennosti-puti-razvitiya

9. Конкурентоспособность национальной инновационной системы России: анадитический обзор. URL: https://cyberleninka.ru/article/n/konkurentosposobnostnatsionalnoy-innovatsionnoy-sistemy-rossii-analiticheskiy-obzor

10. Риановости. URL: https://ria.ru/science/20180710/1524319452.html

11. Global Innovation Index. URL: http://www.globalinnovationindex.org/analysis-indicator.

12. European Innovation Scoreboard 2018. URL: https://ec.europa.eu/docsroom/ documents $/ 33147$

13. ГИИ 2018 г.: Китай стремительно ворвался в двадцятку лидеров; Швейцария, Нидерланды, Швеция, Соединенное Королевство, Сингапур и США удерживают ведущие позиции в годовых рейтингах. URL: http://www.wipo.int/pressroom/ ru/articles/2018/article_0005.html

14. Стан інноваційної діяльності та діяльності у сфері трансферу технологій в Україні у 2017 році/ Аналітична довідка. URL: https://mon.gov.ua/storage/app/media/ innovatsii-transfer-tehnologiy/monitoring-prioritet/stan-id-2017-f.pdf 
15. European Innovation Scoreboard 2017. URL: http://ec.europa.eu/DocsRoom/documents/24829

\section{REFERENCES}

1. Hazuda, L. M., \& Dovba, I. V. (2018). Derzhavne zabezpechennia innovatsiinoho rozvytku rehionu: dosvid zarubizhnykh krain [State support of innovative development of the region: the experience of foreign countries]. Naukovyi visnyk Uzhhorodskoho natsionalnoho universytetu. Seriia: Mizhnarodni ekonomichni vidnosyny ta svitove hospodarstvo - Scientific herald of Uzhhorod National University. Series: International Economic Relations and the World Economy, 20 (1) 96-99 [in Ukrainian].

2. Tatarinov, V. V., \& Tatarinov, V. S. (2013). Opyt razvitiya i finansirovaniya innovatsiy za rubezhom i realii ukrainskogo rynka innovatsiy [Experience in the development and financing of innovations abroad and the reality of the Ukrainian innovation market]. Akademichnyy ohlyad - Academic review 2 (39), 162-169 [in Russian].

3. Opy't innovatsionnogo sotrudnichestva stran ES i SNG. [Experience in innovative cooperation between EU and CIS countries] Retrieved from http://iee.org.ua/files/alushta/31boyko-opyt_innov_sotrudn.pdf [in Russian].

4. Naukova ta innovacijna diyalnist (1990-2016). Dzherela finansuvannya innovacijnoyi diyalnosti. [Scientific and innovative activity (1990-2016). Sources of funding for innovation]. Retrieved from http:// www.ukrstat.gov.ua/ [in Ukrainian].

5. Lopatynskyj, Yu. M., \& Vodyanka, L.D. (2018). Derzhavne regulyuvannya innovacijnoyi diyalnosti: zarubizhnyj dosvid [State regulation of innovation: foreign experience]. Infrastruktura rynku - Market Infrastructure, 16. Retrieved from http:// www.market-infr.od.ua/journals/2018/16_2018_ukr/7.pdf. [in Ukrainian].

6. Nacionalna innovacijna systema SShA: charakterystyky, osoblyvosti, shlyaxy rozvytku. [US National Innovation System: characteristics, features, ways of development] Retrieved from ttps://cyberleninka.ru/article/n/natsionalnaya-innovatsionnaya-sistema-sshaharakteristiki-osobennosti-puti-razvitiya [in Ukrainian].

7. Konkurentosposobnost natsionalnoy innovatsionnoy sistemy $i$ Rossii: analiticheskiy obzor [Competitiveness of the national innovation system of Russia: analytical review]. Retrieved from https://cyberleninka.ru/article/n/konkurentosposobnost-natsionalnoyinnovatsionnoy-sistemy-rossii-analiticheskiy-obzor [in Russian].

8. Rianovosty. [RIA News]. Retrieved from https://ria.ru/science/20180710/1524319452. html [in Russian].

9. GII 2018 g.: Kitay stremitelno vorvalsya v dvadtsatku liderov; Shveytsariya, Niderlandy, Shvetsiya, Soedinennoe Korolevstvo, Singapur i SShA uderzhivayut veduschie pozitsii v godovy'h reytingah [GII 2018: China quickly burst into the top twenty; Switzerland, the Netherlands, Sweden, the United Kingdom, Singapore and the USA hold leading positions in annual ratings]. Retrieved from http://www.wipo.int/pressroom/ru/articles/2018/ article_0005.html [in Russian].

10. Stan innovacijnoyi diyal nosti ta diyal nosti u sferi transferu texnologij v Ukrayini u 2017 roci/Analitychna dovidka [The state of innovation and activity in the field of technology transfer in Ukraine in 2017 / Analytical reference]. Retrieved from https://mon.gov.ua/storage/ app/media/innovatsii-transfer-tehnologiy/monitoring-prioritet/stan-id-2017-f.pdf [in Ukrainian]. 